\title{
Kinetic Study of Aluminum Sulphate and Ammonium Aluminum Sulphate Coagulants in Wastewater Treatment
}

\author{
L.N. Ukiwe ${ }^{a}$, C.I.A. Nwoko ${ }^{b}$, Okere-Chijioke $M^{c}$ \\ ${ }^{\mathrm{a}, \mathrm{b}, \mathrm{c}}$ Department of Chemistry, Federal University of Technology, Owerri, Nigeria \\ Corresponding author: luggil2002@yahoo.com
}

\begin{abstract}
An investigation into the kinetics of two inorganic coagulants namely: aluminum sulphate octadecahydrate $\left(\mathrm{Al}_{2}\left(\mathrm{SO}_{4}\right)_{3} .18 \mathrm{H}_{2} \mathrm{O}\right)$ an ammonium aluminum sulphate dodecahydrate $\left(\mathrm{NH}_{4} \mathrm{Al}\left(\mathrm{SO}_{4}\right)_{2} .12 \mathrm{H}_{2} \mathrm{O}\right)$ was studied to determine the effect of certain kinetic parameters on coagulation performance of the above mentioned coagulants. Results of analysis obtained revealed that the rate constant $(\mathrm{k})$ for $\mathrm{Al}_{2}\left(\mathrm{SO}_{4}\right)_{3} .18 \mathrm{H}_{2} \mathrm{O}$ was $5.727 \mathrm{~s}^{-1}$, while that for $\mathrm{NH}_{4} \mathrm{Al}\left(\mathrm{SO}_{4}\right)_{2} .12 \mathrm{H}_{2} \mathrm{O}$ was $2.282 \mathrm{~s}^{-1}$. However, the order of the reaction $\left(\mathrm{x}_{\mathrm{n}}\right)$ of $\mathrm{Al}_{2}\left(\mathrm{SO}_{4}\right)_{3} .18 \mathrm{H}_{2} \mathrm{O}$ and $\mathrm{NH}_{4} \mathrm{Al}\left(\mathrm{SO}_{4}\right)_{2} .12 \mathrm{H}_{2} \mathrm{O}$ with the wastewater was 1.0 and 1.0, respectively, indicating that both reactions were first order. Considering the mechanism of the reaction, the general trend observed indicated that the $\mathrm{Al}_{2}\left(\mathrm{SO}_{4}\right)_{3} .18 \mathrm{H}_{2} \mathrm{O}$ reaction was thrice as fast as the $\mathrm{NH}_{4} \mathrm{Al}\left(\mathrm{SO}_{4}\right)_{2} .12 \mathrm{H}_{2} \mathrm{O}$ reaction. This fact together with the larger value of $\mathrm{k}$ for $\mathrm{Al}_{2}\left(\mathrm{SO}_{4}\right)_{3} \cdot 18 \mathrm{H}_{2} \mathrm{O}$ obtained in the experiment lend credence to the widely held believe that $\mathrm{Al}_{2}\left(\mathrm{SO}_{4}\right)_{3} .18 \mathrm{H}_{2} \mathrm{O}$ is a more effective coagulant than $\mathrm{NH}_{4} \mathrm{Al}\left(\mathrm{SO}_{4}\right)_{2} .12 \mathrm{H}_{2} \mathrm{O}$ in wastewater treatment.
\end{abstract}

\section{Indexing terms/Keywords}

decomposition, environmental, flood, molecules, reaction, turbidity, wastewater

\section{Academic Discipline And Sub-Disciplines}

Environmental chemistry

\section{SUBJECT CLASSIFICATION}

Chemistry

\section{TYPE (METHOD/APPROACH)}

Experimental

\section{Council for Innovative Research}

Peer Review Research Publishing System

Journal: Journal of Advances in Chemistry

Vol 3, No.3

\section{editor@cirworld.com}




\subsection{INTRODUCTION}

Climate change is a well known phenomenon which has become a painful reality. As well as increasing atmospheric temperature, climate change alters weather conditions with deleterious effects to agriculture, ecosystem, and water needs and supply. The effect of climate change could be vast and often lead to sea-level rise with attendant consequences such as floods. In sub-Sahara Africa, it's been estimated that about 1.5 million people have been killed by floods in the past decade (1). Flood situations give rise to emergencies where the population is displaced and placed in emergency camps with the possibility of scarcity of portable drinking water since water courses are inundated and safe drinking water becomes unavailable and relatively expensive to produce. Human activities during flood situations tend to pollute water supplies since facilities such as public conveniences are also inundated. Because of the difficulties associated in getting clean drinking water during this period, the population may resort to drinking waters from streams, lakes or rivers. These water sources may have been contaminated by storm-water run-offs which wash debris, feces and chemicals into streams, lakes and rivers. Hence, in order to avoid diseases such as diarrhea, cholera and typhoid associated with consuming contaminated water, it becomes imperative that emergency water treatment processes are put in place to provide clean, safe drinking water for the population.

Water treatment depends on end-use and sources. Treatment of water should encompass the different sources of water so as to achieve wide application and usage. Water for drinking purposes should be free from all kinds of bacteria and microorganisms. It must contain soluble minerals salts within agreeable limits, it should be tasteless and should not be turbid and colored (2).

Coagulation/flocculation is an important aspect of water treatment that aimed at removing color, turbidity and some forms of bacteria in water and wastewater. Coagulation removes colloids and suspended solids from water. These particles have a negative charge; hence, the positively charged coagulant chemicals neutralize these negative charges during coagulation. The flocculation process aggregates the particles together by Van der Waals forces forming flocs (3). The coagulation/flocculation process is affected by $\mathrm{pH}$, inorganic salt, alkalinity, temperature of water, rate of mixing, and type of coagulation chemical (4). Coagulants come in two main types, namely; primary coagulants and coagulant aids. Primary coagulants neutralize the electrical charges of particles in the water which cause the particles to floc together, but coagulant aids function by adding density to slow-settling flocs thereby adding toughness to the flocs in order that they don't break up during the mixing and settling processes. Primary coagulant maybe classified as inorganic coagulant, while organic coagulants are basically coagulant aids. Inorganic coagulants include; sulphates of aluminum and iron. Polydiallyldimethyl ammonia chloride is an example of organic coagulant (5). Coagulation and flocculation are two distinct unit processes in wastewater treatment. Sajjad and Javed (6) investigated the use of aluminum sulphate $\left(\mathrm{Al}_{2}\left(\mathrm{SO}_{4}\right)_{3} .18 \mathrm{H}_{2} \mathrm{O}\right.$; alum) and a cationic polymer to treat tannery wastewater and observed that the combination of alum with the cationic polymer resulted in effective turbidity removal of about $97 \%$. Impacts of anionic polymer compound bioflocculant (CBF) as a coagulant aid on coagulation and floc performance with titanium tetrachloride $\left(\mathrm{TiCl}_{4}\right)$ and alum have been examined (7). Results obtained indicated that $\mathrm{CBF}$ with $\mathrm{TiCl}_{4}$ or alum showed great synergistic effects by encouraging dissolved organic carbon (DOC) removal from the system. A study on particle size distribution in wastewater before and after coagulation to determine the efficiency of the coagulation-flocculation process noted that when alum was used without coagulant aids, overall efficiency of particle removal was $87 \%$, whereas, addition of coagulant aid improved removal efficiency of the process by about $98 \%$ (8). By separately applying ferric chloride $\left(\mathrm{FeCl}_{3}\right)$, aluminum chloride $\left(\mathrm{AlCl}_{3}\right)$ and alum on wastewater, the effectiveness of these coagulants were tested in wastewaters to evaluate turbidity removal from wastewaters (9). It was revealed that among the three coagulants tested, $\mathrm{AlCl}_{3}$ gave the best results at $\mathrm{pH} 6$ and 9 . However, at $\mathrm{pH} 7.5$ it was noted that the turbidity removal efficiency of the three coagulants were almost identical. At an optimum $\mathrm{pH}$ of $6.0,78 \%$ of color reduction has been obtained when copper sulphate was used as coagulant in treating paper mill effluent (10). Recent investigations on inorganic coagulants include studies of Garg et al, (11) who examined the effectiveness of coagulant and acid precipitation processes for the pre-treatment of dilute black liquor and Amuda et al, (12) who also observed the effectiveness of $\mathrm{FeCl}_{3}$ in treating beverage industrial wastewater to remove trace metals there-in. Marañón et al, (13) equally investigated the application of different coagulants and flocculants to leachate to determine the optimum conditions for removal of organic matter, color and turbidity.

\subsection{Theoretical principles of coagulation/flocculation kinetics}

The effectiveness of a coagulant is generally dependent on the velocity of shearing or breaking of the coagulant and the formation of flocs particles. The velocity of shearing is a function of the rate of the reaction. A theoretical equation that describes the velocity of the coagulation-flocculation process is called a "rate law". The reaction of alum and $\mathrm{NH}_{4} \mathrm{Al}\left(\mathrm{SO}_{4}\right)_{2} .12 \mathrm{H}_{2} \mathrm{O}$ with water is shown below:

$\mathrm{Al}_{2}\left(\mathrm{SO}_{4}\right)_{3} .18 \mathrm{H}_{2} \mathrm{O}+3 \mathrm{Ca}\left(\mathrm{HCO}_{3}\right)_{2} \rightarrow 2 \mathrm{Al}(\mathrm{OH})_{3}+3 \mathrm{CaSO}_{4}+6 \mathrm{CO}_{2}+18 \mathrm{H}_{2} \mathrm{O}$

$2\left(\mathrm{NH}_{4}\right) \mathrm{Al}\left(\mathrm{SO}_{4}\right)_{2} .12 \mathrm{H}_{2} \mathrm{O}+4 \mathrm{Ca}\left(\mathrm{HCO}_{3}\right)_{2} \rightarrow 2 \mathrm{NH}_{4} \mathrm{OH}+4 \mathrm{CaSO}_{4}+2 \mathrm{Al}(\mathrm{OH})_{3}+8 \mathrm{CO}_{2}+12 \mathrm{H}_{2} \mathrm{O}$

The velocity of the reaction is defined as the decrease in reactant (coagulant) with time. Hence;

$\mathrm{V}=\mathrm{d}[\mathrm{A}] / \mathrm{dt}$

Where $[\mathrm{A}]$ is the concentration of the reactant and, $t$, is the time.

Therefore, using a proportionality constant or rate constant, $k$, the velocity of the reaction is then given as

$$
-k[A]=d[A] / d t
$$

Rearranging equation 4 and integrating, we have 
$\ln [A]=-k t+$ constant

Integrating between initial concentration of $A_{\circ}$ and the concentration of $A$ at time, $t$, the constant in equation 5 is equal to Ao the initial concentration. Thus,

$$
\ln [A]=-k t+\ln \left[A_{0}\right]
$$

So, a plot of $\operatorname{In}[\mathrm{A}]$ versus time, $t$, gives a straight line for a first order reaction whose rate constant, $k$, is the slope (14). For a reaction to be first order, the concentration of the reactant $\left[A_{t}\right]$ at time $(t)$ is related to the initial concentration $[A o]$ as follows:

$\log \left[A_{t}\right]=-k t / 2.303+\log \left[A_{\circ}\right]$

A plot of log [At] versus time $(t)$ gives a straight line whose slope is equal to $-k / 2.303$. This affords a method for obtaining the rate constant of a first order reaction. If the plot is a non-linear curve, then the reaction is not first order (15).

The present study aimed at investigating the rate of dissolution of alum and $\left(\mathrm{NH}_{4}\right) \mathrm{Al}\left(\mathrm{SO}_{4}\right)_{2} .12 \mathrm{H}_{2} \mathrm{O}$ coagulants in wastewater with a view to determining which of the two coagulants is most effective in wastewater treatment.

\subsection{Materials and Methods}

\subsection{Sample preparation}

The wastewater used in this experiment was prepared by mixing $1 \mathrm{~kg}$ of muddy soil with $2 \mathrm{~L}$ of tap water. This was done to simulate a wastewater type obtained during flood situations. The mixture was stirred thoroughly at $65 \mathrm{rpm}$ using a centrifuge (MC5415C, Akson Scientific Instrument, Akwa, Nigeria) for $10 \mathrm{~min}$ and allowed to stand for $1 \mathrm{hr}$. Debris and particles were removed by screening and filtration through a $10 \mathrm{~mm}$ mesh sieve and the supernatant decanted into a $5 \mathrm{~L}$ beaker. The $\mathrm{pH}$ of the mixture was adjusted to 8.0 using a pH meter (PHS 25, Shanghai. Xinrui Instrument, China) by adding $\mathrm{NaOH} / \mathrm{HCl}$ as appropriate. This mixture was used as the stock solution.

\subsection{Coagulation/flocculation experiment}

The experiments were all done by applying conventional "jar test" method. All the experiments were carried out at room temperature. One hundredth millilitres $(100 \mathrm{ml})$ of the stock solution was measured into a $200 \mathrm{ml}$ beaker and $1 \mathrm{~g}$ of alum was weighed and added to the stock in the $200 \mathrm{ml}$ beaker. The mixture was stirred repeatedly with a centrifuge at $25 \mathrm{rpm}$ for 5 min until the coagulant dissolved completely. The mixture was left to stand for $30 \mathrm{~min}$. After this period, a $5 \mathrm{ml}$ portion was withdrawn into a $10 \mathrm{ml}$ beaker using a plastic syringe and three drops of a $20 \% \mathrm{v} / \mathrm{v} \mathrm{HCl}$ solution was added to the mixture in the $10 \mathrm{ml}$ beaker, followed by an addition of $5 \mathrm{ml}$ of barium chloride $\left(\mathrm{BaCl}_{2}\right)$ solution. A white precipitate was obtained which was recovered by decanting the supernatant solution. The precipitate was dried at $60^{\circ} \mathrm{C}$ in an $\mathrm{Oven}$ (Unicon Electric Oven, GE-108, Bombay, India) until constant weight. Three repeations were performed and the mean weight of the precipitate was multiplied by a factor of 10 and then divided by the molar mass of the coagulant to obtain the concentration of the coagulant in $\mathrm{molL}^{-1}$. This procedure was repeated after every $30 \mathrm{~min}$ for $5 \mathrm{hr}$. The entire procedure was also repeated using $\left(\mathrm{NH}_{4}\right) \mathrm{Al}\left(\mathrm{SO}_{4}\right)_{2} .12 \mathrm{H}_{2} \mathrm{O}$.

A graph of concentration ( $\mathrm{molL}^{-1}$ ) versus time $(\mathrm{t})$ was plotted and the initial rate was calculated for two experimental points. The rate law for alum was obtained by applying the equation:

$$
\begin{aligned}
& \mathrm{Al}_{2}\left(\mathrm{SO}_{4}\right)_{3} .18 \mathrm{H}_{2} \mathrm{O}+3 \mathrm{Ca}\left(\mathrm{HCO}_{3}\right) \rightarrow 2 \mathrm{Al}(\mathrm{OH})_{3}+3 \mathrm{CaSO}_{4}+18 \mathrm{H}_{2} \mathrm{O}+6 \mathrm{CO}_{2} \\
& \text { and the Formulae: }
\end{aligned}
$$

Rate $=\mathrm{K}_{1}[\mathrm{~A}]^{\mathrm{X}}[\mathrm{B}]^{\mathrm{y}}$

Where $[\mathrm{A}]$, represent the concentration of $\mathrm{Al}_{2}\left(\mathrm{SO}_{4}\right)_{3} .18 \mathrm{H}_{2} \mathrm{O}$ and $[\mathrm{B}]$, represent the concentration of

$\mathrm{Ca}\left(\mathrm{HCO}_{3}\right)_{2} . \mathrm{x}$ and $\mathrm{y}$ are the order of the reaction.

Hence, applying equation 9 to the reaction 8 ,

we have:

$$
\begin{aligned}
& \text { Rate }_{1}=\mathrm{K}_{1}\left[\mathrm{Al}_{2}\left(\mathrm{SO}_{4}\right)_{3}\right]_{1}{ }^{\mathrm{x} 1}\left[\mathrm{Ca}\left(\mathrm{HCO}_{3}\right)_{2}\right]_{1}{ }^{\mathrm{y} 1} \\
& \text { Rate }_{2}=\mathrm{K}_{2}\left[\mathrm{Al}_{2}\left(\mathrm{SO}_{4}\right)_{3}\right]_{2}{ }^{\mathrm{x} 2}\left[\mathrm{Ca}\left(\mathrm{HCO}_{3}\right)_{2}\right]_{2}{ }^{\mathrm{y} 2}
\end{aligned}
$$

The concentration of $\mathrm{Ca}\left(\mathrm{HCO}_{3}\right)_{2}$ was determined through titrimetry using the equation:

$\mathrm{Ca}\left(\mathrm{HCO}_{3}\right)_{2}+\mathrm{H}_{2} \mathrm{SO}_{4} \rightarrow \mathrm{CaSO}_{4}+2 \mathrm{CO}_{2}+2 \mathrm{H}_{2} \mathrm{O}$

By applying the method described by Vogel(16).

Rate of reaction does not depend on the concentration of $\mathrm{Ca}\left(\mathrm{HCO}_{3}\right)_{2}$ in water, which is true for any aqueous reaction which water is a reactant. Hence, the reaction is zero order with respect to $\mathrm{Ca}\left(\mathrm{HCO}_{3}\right)_{2}$. 
Therefore, combining equation 10 and 11

Rate $_{2} /$ Rate $\left._{1}=\underline{K}_{2}\left[\underline{A l}_{2} \underline{2} \underline{S O}_{4}\right)_{3}\right]_{2}{ }^{X} \times[C$

$$
\mathrm{K}_{1}\left[\mathrm{Al}_{2}\left(\mathrm{SO}_{4}\right)_{3}\right]_{1}{ }^{\mathrm{X} 1} \times\left(\mathrm{Ca}\left(\mathrm{HCO}_{3}\right)_{2}\right]_{1}^{\mathrm{Y} 1}
$$

Rate $_{1}=$ Difference in concentration of the first and second experiments divided by the difference in time from zero to 30min

Rate $_{2}=$ Difference in concentartion of the second and third experiments divided by the difference in time from $30 \mathrm{~min}$ to $1 \mathrm{hr}$.

$\left[\mathrm{Al}_{2}\left(\mathrm{SO}_{4}\right)_{3}\right]_{1}$ is the difference in concentration value of the first and second experiments.

$\left[\mathrm{Al}_{2}\left(\mathrm{SO}_{4}\right)_{3}\right]_{2}$ is the difference in concentration value of the second and third experiments.

So equation 13 now becomes ;

Rate $_{2} /$ Rate $_{1}=\underline{K}_{2}\left[\mathrm{Al}_{2}\left(\mathrm{SO}_{4}\right)_{3}\right]_{2}{ }_{2}^{\mathrm{X}}\left[\mathrm{Ca}\left(\mathrm{HGO}_{3}\right)_{2}\right]_{2}{ }^{\mathrm{Y}}$

$$
\mathrm{K}_{4}\left[\mathrm{Al}_{2}\left(\mathrm{SO}_{4}\right)_{3}\right]_{1}{ }^{\mathrm{X} 1}\left(\mathrm{Ca}\left(\mathrm{HCO}_{3}\right)_{2}\right]_{1}^{\mathrm{Y} 1}
$$

Furthermore, equation (14) yield

Rate $_{2} /$ Rate $_{1}=\left[\mathrm{Al}_{2}\left(\mathrm{SO}_{4}\right)_{3}\right]_{2}{ }^{\mathrm{X} 2} /\left[\mathrm{Al}_{2}\left(\mathrm{SO}_{4}\right)_{3}\right]_{1}{ }^{\mathrm{X} 1}$

However, equation (15) summarizes to

Rate $_{2} /$ Rate $_{1}=\left(\mathrm{Al}_{2}\left(\mathrm{SO}_{4}\right)_{3} / \mathrm{Al}_{2}\left(\mathrm{SO}_{4}\right)_{3}\right)^{\mathrm{x}} \mathrm{n}$

$\mathrm{X}_{\mathrm{n}}$ : Represent the order of the reaction when alum is used as the coagulant. The procedure above was applied using $\mathrm{NH}_{4} \mathrm{Al}\left(\mathrm{SO}_{4}\right)_{2} .12 \mathrm{H}_{2} \mathrm{O}$ using equation 2 .

The rate constant $(k)$ each of both coagulants was calculated using the equation below;

Rate $_{1}=\mathrm{K}[\mathrm{A}]^{\mathrm{Xn}}$

where $[A]$ represented the concentration of each coagulant.

\subsection{Results}

Table 1: Mean values of the Kinetic data for the decomposition of $\mathrm{Al}_{2}\left(\mathrm{SO}_{4}\right)_{3} .18 \mathrm{H}_{2} \mathrm{O}$ to products.

\begin{tabular}{|l|l|}
\hline Time (min) & $\begin{array}{l}\text { Concentration }\left(\mathrm{molL}^{-1}\right) \\
\text { (mean } \pm \mathrm{SD})\end{array}$ \\
\hline 30 & $0.870 \pm 0.2$ \\
\hline 60 & $0.381 \pm 0.2$ \\
\hline 90 & $0.299 \pm 0.1$ \\
\hline 110 & $0.263 \pm 0.2$ \\
\hline 140 & $0.240 \pm 0.1$ \\
\hline 170 & $0.221 \pm 0.1$ \\
\hline 200 & $0.210 \pm 0.1$ \\
\hline 230 & $0.199 \pm 0.2$ \\
\hline 260 & $0.196 \pm 0.2$ \\
\hline 290 & $0.193 \pm 0.2$ \\
\hline $\mathrm{X}_{\mathrm{n}}\left(\mathrm{Al}_{2}\left(\mathrm{SO}_{4}\right)_{3}=1.0\right.$ & \\
$\mathrm{K}\left(\mathrm{Al}_{2}\left(\mathrm{SO}_{4}\right)_{3}=5.727 \mathrm{~s}^{-1}\right.$ & \\
\hline
\end{tabular}




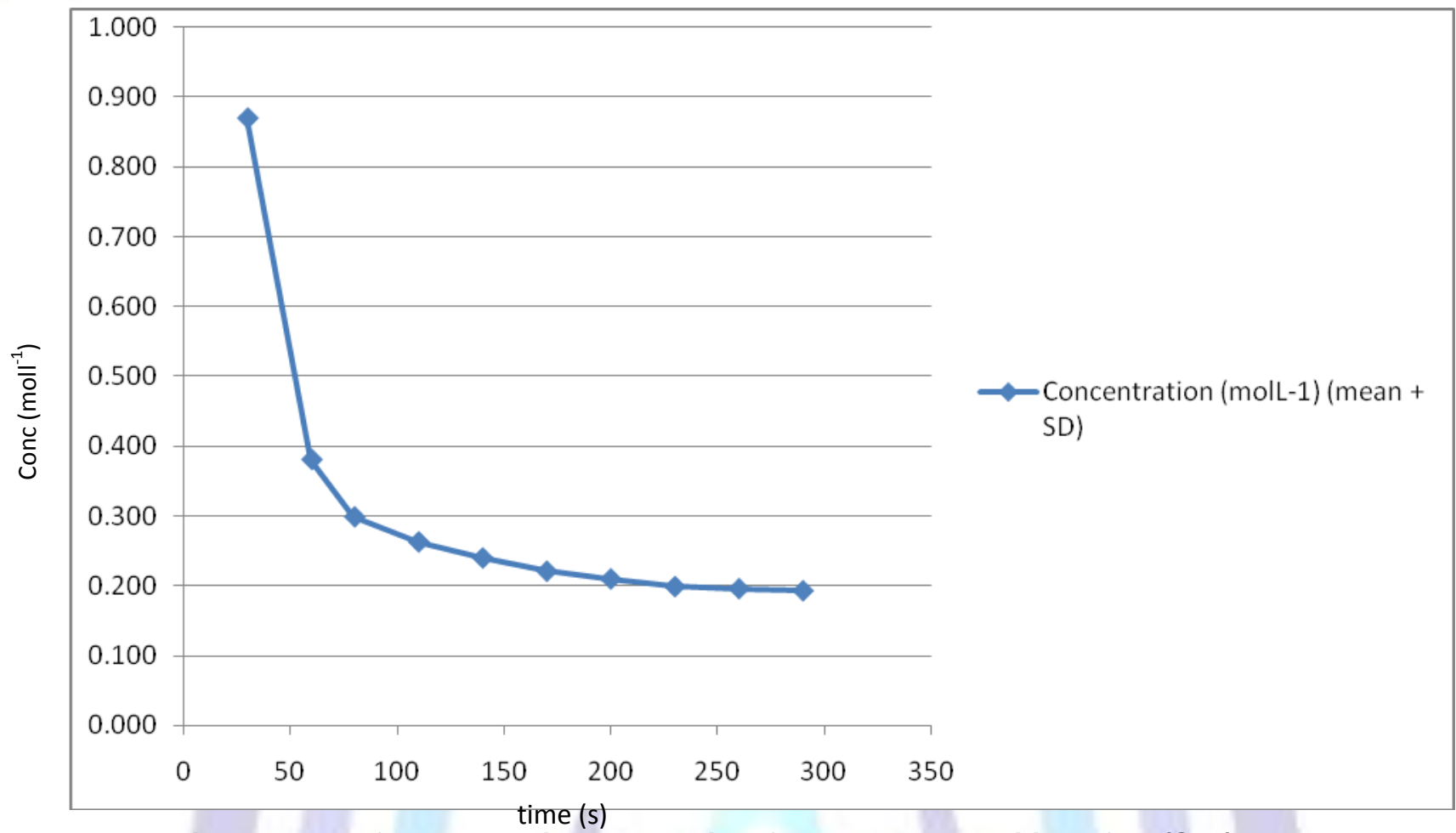

Fig 1: Graph of concentration versus time for the decomposition of $\mathrm{Al}_{2}\left(\mathrm{SO}_{4}\right)_{3} .18 \mathrm{H}_{2} \mathrm{O}$

Table 2: Mean values of the Kinetic data for the decomposition of $\left(\mathrm{NH}_{4}\right) \mathrm{Al}\left(\mathrm{SO}_{4}\right)_{2} \cdot 12 \mathrm{H}_{2} \mathrm{O}$ to products.

\begin{tabular}{|l|l|}
\hline Time $(\mathrm{min})$ & $\begin{array}{l}\text { Concentration }\left(\mathrm{molL}^{-1}\right) \\
(\text { mean } \pm \text { SD })\end{array}$ \\
\hline 30 & $0.633 \pm 0.1$ \\
\hline 60 & $0.548 \pm 0.1$ \\
\hline 90 & $0.506 \pm 0.1$ \\
\hline 110 & $0.422 \pm 0.2$ \\
\hline 140 & $0.380 \pm 0.1$ \\
\hline 170 & $0.337 \pm 0.1$ \\
\hline 200 & $0.324 \pm 0.1$ \\
\hline 230 & $0.300 \pm 0.2$ \\
\hline 260 & $0.253 \pm 0.2$ \\
\hline 290 & $0.222 \pm 0.2$ \\
\hline
\end{tabular}

$\mathrm{X}_{\mathrm{n}}\left(\mathrm{NH}_{4}\right) \mathrm{Al}\left(\mathrm{SO}_{4}\right)_{2}=1.0$

$\mathrm{K}\left(\mathrm{NH}_{4}\right) \mathrm{Al}\left(\mathrm{SO}_{4}\right)_{2}=2.383 \mathrm{~s}^{-1}$ 


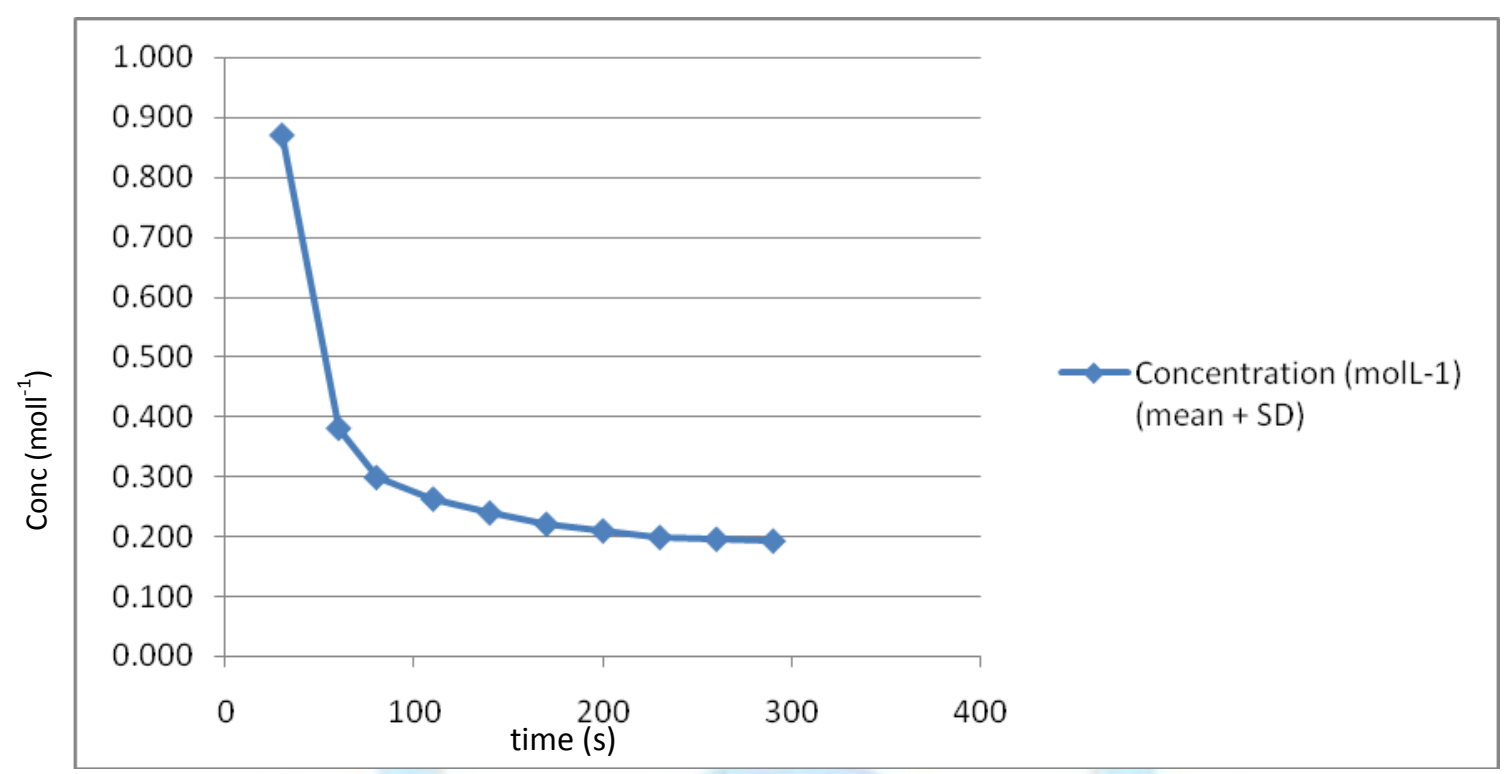

Fig 2: Graph of concentration versus time for the decomposition of $\left(\mathrm{NH}_{4}\right) \mathrm{Al}\left(\mathrm{SO}_{4}\right)_{2} \cdot 12 \mathrm{H}_{2} \mathrm{O}$.

\subsection{Discussion}

For any coagulant to be applied effectively in treating wastewater, a knowledge of the rate of the coagulants reaction as well as its mechanism is required. The mechanism of the reaction reveals how fast or slow the coagulant react with the wastewater. This is essential in determining which coagulant would be the most effective during emergency situations. The order of the reaction is useful mainly as a base to indicate the type of reaction and it is seen as an apparent molecularity tool to lead us to understand the mechanism of the reaction (15).

Fig 1 and 2 show the rate of change of alum and $\mathrm{NH}_{4} \mathrm{Al}\left(\mathrm{SO}_{4}\right)_{2}$ in wastewater at various times at room temperature. It was observed that between 30 to $60 \mathrm{~min}$, the rate of decompositiom of alum was three times as fast as that between 60 to 90 min. This makes perfect sense when considering molecularity of reactants, since as alum molecules are used up, it is expected that fewer molecules remain to collide with water molecules, hence, a decrease in the reaction rate of alum. However, in Fig 2, the rate of decomposition of $\mathrm{NH}_{4} \mathrm{Al}\left(\mathrm{SO}_{4}\right)_{2}$ between 30 to 60 min was so negligible when compared to the dissociation of the coagulant between 60 to $90 \mathrm{~min}$. And comparing the dissociation rate of both coagulants between 30 to $60 \mathrm{~min}$, it was observed that alum dissociates thrice as fast as $\mathrm{NH}_{4} \mathrm{Al}\left(\mathrm{SO}_{4}\right)_{2}$ within the same period. The rate constant $(\mathrm{k})$ for alum was observed to be $5.727 \mathrm{~s}^{-1}$, while that for $\mathrm{NH}_{4} \mathrm{Al}\left(\mathrm{SO}_{4}\right)_{2}$ was $2.383 \mathrm{~s}^{-1}$. Nontheless, the order of the alum reaction $\left(x_{n}\right)$ with water was obtained as 1.0, while that for $\mathrm{NH}_{4} \mathrm{Al}\left(\mathrm{SO}_{4}\right)_{2}$ was also noted to be 1.0. These orders of reaction indicated that both recations were first order with respect to the coagulant. The general trend in the graphs showed that as the coagulants were used-up, fewer particles were thus present within the system as time increases, hence, $\mathrm{k}$ relates to the rate of reaction inversely. Fridkhsberg (17) had earlier noted that for a condition of high value of $k$ to be obtained, there should be low values for the rate of reaction. The order of the reaction $\left(x_{n}\right)$ obtained for both coagulants conforms with the argument noted by several studies including that of (18) who demonstrated that the coagulation process is guilded by Brownian motion where colloidal particles have single phase charges, mutually repelling one another and donot aggregate to large masses, but could settle only when substances such as coagulants are added to the system to gather the single phase charges, floc them to grow, so as to settle under gravity. $k$ values are important determinant in selecting effective coagulants for water purification (19). The higher the $k$ value of the coagulant, the more effective the coagulant. The $\mathrm{k}$ value for alum obtained in the present study indicated that alum is an effective and preferred coagulant to $\mathrm{NH}_{4} \mathrm{Al}\left(\mathrm{SO}_{4}\right)_{2}$ in wastewater treatment.

The ability to predict the rate law of a coagulation reaction process is of great assistance in establishing the reaction mechanism. The present study has noted that alum reaction is faster than $\mathrm{NH}_{4} \mathrm{Al}\left(\mathrm{SO}_{4}\right)_{2}$ reaction. Rate of reaction is dependent on the number of collisions between reactant, which is also proportional to the concentration of the reactants. Though variations in reaction rate are observed through concentration changes, it is expected that molecular orientation would influence the number and rate of collision (3). Alum posses high charge and dissociates to the $\mathrm{Al}^{+3}$ trivalent ion which hydrates to form an aquometal complex which passes through a series of hydrolytic reactions forming mononuclear specie. The high positive charge of the mononuclear specie enable alum molecules to easily interact with negative charges, thus coagulating them through electrostatic action. This molecular orientation principle is one of the most important reasons why alum is preferred to other coagulants in wastewater treatment. 


\section{REFERENCES}

(1) WFP., Floods across sub-saharan Africa hit 1.5 million people, (2007). Available on-line: http//:www.wfp.org

(2) Makris, K.C., Ardra, S.S., Herrick, L., Christophi, C.A., Snyder, S.A., \& Hauser, R. Association of drinking water source and use characteristics with urinary antimony concentrations. Journal of Exposure Science and Environmental Epidemiology, (2013). 23: 120-127.

(3) Koohestanian, A., Hosseini, M., \& Abbasian, Z. The separation method for removing of colloidal particles from raw water. American-Eurasian Journal of Agriculture \& Environmental Science, (2008). 4: 266-273.

(4) Ukiwe, L.N., \& Alinnor, J.I. Assessment of polyacrylamide and aluminum sulphate coagulants in turbidity removal in wastewater. Terrestrial and Aquatic Environmental Toxicology, (2012). 6: 132-135.

(5) Gebbie, P., An operator's guild to water treatment coagulants, In: Proceedings of the $31^{\text {st }}$ Annual Water Industry Workshop-operations Skills, Rockhampton,USA: 2000, pp14-20, 4-6 July

(6) Hayder, S., \& Aziz, J.A. Coagulation-flocculation studies of tannery wastewater using combination of alum with cationic and anionic polymers. Journal of Hazardous Materials, (2009). 168: 1035-1040.

(7) Zhao, Y.X., Gao, B.Y., Shon, H.K., Wang, Y., Kim, J.H., Yue, Q.Y., \& Bo, X.W. Anionic polymer compound bioflocculant as a coagulant aid with aluminum sulfate and titanium tetrachloride. Bioresource Technology, (2012). 108: 45-54.

(8) Aguilar, M.I., Sáez, J., Lloréns, M., Soler, A., \& Ortuño, J.F. Particle size distribution in slaughterhouse wastewater of natural stone processing by coagulation/flocculation methods. Environmental Progress, (2003). 22: 183-188.

(9) Ersoy, B., Tosun, I., Günay, A., \& Diknen, S. Turbidity removal from wastewaters of natural stone processing by coagulation/flocculation methods. Clean-Soil, Air, Water, (2009). 37: 225-232.

(10) Chaudhari, P.K., Majumdar, B., Choudhary, R., Yadav, D.K., \& Chand, S. Treatment of paper and pulp mill effluent by coagulation. Environmental Technology, (2010). 31: 357-363.

(11) Garg, A., Mishra, I.M., \& Chand, S. Effectiveness of coagulation and acid precipitation process for the pre-treatment of diluted black liquor. Journal of Hazardous Materials, (2010). 180: 158-164.

(12) Amuda, O.S., Amoo, I.A., Ipinmoroti, K.O., \& Ajayi, O.O. Coagulation/flocculation process in the removal of trace metals present in industrial wastewater. Journal of Applied Science and Environmental Management, (2006). 10: 159-162.

(13) Marañón, E., Castrillón, L., Fernández, N.Y., Fernández, \& M.A., Fernández, S.A. Color, turbidity and COD removal from old landfill leachate by coagulation-flocculation treatment. Waste Management Research, (2010). 28: $731-738$.

(14) Silberberg, M.S. Chemistry: The molecular nature of matter and change ( ${ }^{\text {nd }}$ Edn.). New York, USA: McGraw-Hill Companies. pp. 664-680.

(15) Ausiem, A.C.I. Principles of general chemistry (4 ${ }^{\text {th }}$ Edn.). 2004. Port Harcourt, Nigeria: Versatile Publishers. pp. $311-$ 340.

(16) Vogel, A.I. Modern methods in quantitative chemical analysis (6 ${ }^{\text {th }}$ Edn.). 2004. Deihi, India: Pearson Education Ltd. pp. 312-356.

(17) Fridrikhsberg, D.A. A course in colloid chemistry (4 ${ }^{\text {th }}$ Edn.). 1984. Moscow, Russia: Mir Publishers. pp386-390.

(18) Menkiti, M.C., Igbokwe, P.K., Ugodulunwa, F.X.O., \& Onukwuli, O.D. Rapid coagulation/flocculation kinetics of coal effluents with high organic content using blended and unblended chitin derived coagulants (CSC). Research Journal of Applied Sciences, (2008). 3: 317-323.

(19) Ugonabo, V.I., Menkiti, M.C., Osoka, E.C., Atuanya, C.U., \& Onukwuli, O.D. Kinetic modeling and functional parameters evaluation of mass transfer rate on bio-coagulant interface in pharmaceutical industry effluent. International Journal of Basic \& Applied Sciences, (2013). 13: 33-47. 